\title{
Recycling Irrigation Water on Ornamental Nursery Operations: Could Consumer Premiums Compensate for Grower Adoption Costs?
}

\author{
Xiang Cao, Darrell Bosch ${ }^{1}$, and James Pease \\ Department of Agricultural and Applied Economics, Virginia Tech, \\ Hutcheson Hall, 250 Drillfield Drive, Blacksburg, VA 24060
}

Additional index words. irrigation, water recycling, nursery production, eco-labeling

\begin{abstract}
The U.S. nursery and greenhouse industry is facing twin challenges of reduced water availability and increased pressure to mitigate pollution from horticultural production. Water-recycling technology (WRT) has been adopted by some nursery producers to improve crop water productivity and to enhance water supply security. This study estimated the economic feasibility of WRT adoption if producers received some portion of retail price premiums for eco-labeled products. Three annual bedding plants, Geraniums (Pelargonium spp.), Petunias (Petunia spp.), and Chrysanthemums (Chrysanthemum spp.) and three broadleaf evergreen plants, Azaleas (Rhododendron spp.), Holly (Ilex spp.), and Boxwood (Buxus spp.) were analyzed based on their sales in the study region of Virginia (VA), Maryland (MD), and Pennsylvania (PA). Of the eight case study nurseries and two synthesized nurseries examined, five showed increased net costs with recycling. However, in almost all cases for which at least a portion of a retail consumer premium was returned to growers, the premium was adequate to compensate for recycling investment costs.
\end{abstract}

Productivity of irrigation water use and contaminant runoff control are becoming increasingly important to nursery and greenhouse growers as well as to policymakers and the public. Increased attention to minimizing total applications of water to obtain a healthy plant (water use productivity) is prompted by water scarcity in U.S. regions such as the West as well as by environmental concerns about agricultural runoff. Concern for water quality in the Chesapeake Bay and its tributaries led the U.S. Environmental Protection Agency (USEPA, 2010) to issue a Total Maximum Daily Load plan for reducing nitrogen, phosphorus, and sediment runoff in the Chesapeake Bay watershed. Under increasing pressure to adopt solutions to address regulatory and drought concerns, some nurseries have adopted WRT, which involves capturing and recycling irrigation water to improve crop water productivity and

\footnotetext{
Received for publication 17 May 2017. Accepted for publication 24 Oct. 2017.

Funding for this work was provided, in part, by the Specialty Crop Research Initiative (SCRI) of USDA - National Institute of Food and Agriculture (NIFA) Award \#2010-51181-21140, Virginia Agricultural Experiment Station and the Hatch Program of the National Institute of Food and Agriculture, U.S. Department of Agriculture.

The authors express appreciation to Nate Ferraro, David Hartter, Alyssa Cultice, and Kevin Boyle for providing data used in this study. Kurt Stephenson and James Owen provided helpful comments on an earlier version of the manuscript.

${ }^{1}$ Corresponding author. E-mail: bosch@vt.edu.
}

to enhance water supply security while reducing contaminants lost from nursery and greenhouse production sites. It is estimated that a 0.4 ha (1-acre) greenhouse producing ornamental crops requires $\approx 83,270 \mathrm{~L}(22,000$ gallons) daily for irrigation, and container nursery operations may require up to $102,195 \mathrm{~L}$ (27,000 gallons) daily (Bailey et al., 1999; Robbins, 2010). With WRT, it is estimated that $40 \%$ to $50 \%$ of water applied could be conserved through recapture and reuse of both irrigation water and any storm water runoff (Wilson and von Broembsen, n.d.), thus increasing security of water supplies and reducing pollutant loads to nearby surface waters. Ferraro et al. (2017) provided detailed analysis of recycling requirements and costs for VA, MD, and PA nurseries.

Long-term access to secure irrigation water supply is of critical importance to nursery growers. WRT also can potentially provide social benefits by reducing discharge to streams and rivers of polluted water from horticultural operations. In some cases, the increased risk of water-borne plant pathogens spreading through recycled water has impeded WRT adoption and associated social benefits from reduced water pollution (Hong and Moorman, 2005; von Broembsen, 1998). In addition, the concern about production cost increases associated with WRT, and the uncertainty of revenue enhancement discourage many growers from implementing the new technology (Cultice et al., 2016).

Many retail customers of horticultural products are concerned about environmental degradation and are now more aware of environmental aspects of production. Previous research has indicated that consumers are willing to pay premiums for plants produced and labeled as "environmentally friendly" or "eco-friendly" (Behe et al., 2014; Gardner et al., 2002; Michaud et al., 2012; Yue et al., 2010). Plants grown with WRT qualify for such a designation because WRT reduces discharge of polluted water. For example, consumers are willing to pay more for "ecolabelled" roses certifying eco-friendly cultivation practices (Michaud et al., 2012). Eco-labeling of environmentally friendly or "green" products has gained interest because environmental practices are highlighted (e.g., using recycled water). Consumers receive more information about the product, and new market opportunities and potential higher profits may be generated. In addition, contract farming has become more common in the U.S. horticulture industry (MacDonald, 2015). Contracting producers and wholesale purchasers such as landscapers or retailers such as "big-box" stores should share price premiums obtained from consumers with contracting producers as financial incentives to promote adoption of conservation practices such as WRT. Little research has been conducted as to how such price premiums might be transmitted through stages of the distribution system from consumers back to growers, or how such premiums relate to costs incurred by growers to produce such eco-labeled attributes. In this case, nursery growers find it hard to obtain useful economic information about the profit potential of WRT and its anticipated effect on their business' long-term bottom line.

Will consumer premiums for plants grown with recycled water be sufficient to make WRT economically practical? This analysis evaluates the economic effects of labeling plants grown with WRT in selected nursery operations in the mid-Atlantic region of VA, MD, and PA. The goal is to estimate the economic feasibility of WRT production practices, which include capturing and recycling rainfall and irrigation runoff, combined with plant eco-labeling, and to determine how such a program would affect greenhouse/nursery production costs, gross revenues, and net revenues. Research results can help nursery growers and policymakers assess WRT adoption to improve crop water productivity and to reduce pollution of offsite surface waters.

\section{Literature Review}

Driven by increased awareness of the need for environmental protection, green products have become more popular among consumers in both food and non-food marketing systems. A so-called "green" product usually refers to a product produced with methods that improve environmental quality or reduce environmental pollution compared with an equivalent product produced with conventional practices (Durif et al., 2010). For example, plants grown with WRT could be considered "green" because recycling water may reduce discharge of polluted water 
to rivers and streams. Schlegelmilch et al. (1996) illustrated that consumer environmental consciousness has positive effects on their purchasing decisions for green products. Laroche et al. (2001) investigated the profile of consumers willing to pay more for green products generally including their demographics, attitudes toward environmentally friendly programs, daily behavior, and personal values. They found this segment of consumers was more likely to be female, married, and with at least one child living at home.

Horticultural products provide both private and public benefits for consumers. Private product benefits are limited to the buyer, whereas public benefits are available to the buyer as well as others. For example, if a horticultural product is produced in a manner that reduces or eliminates pollutants, the product presents a public benefit. Consumers cannot readily evaluate some public benefits such as reduced pollution unless these attributes are communicated via product labeling. Research has found that consumers prefer and are willing to pay a price premium for horticultural products that promise environmental benefits (Behe et al., 2013, 2014; Gardner et al., 2002; Hartter, 2012; Khachatryan et al., 2014; Michaud et al., 2012; Yue et al., 2010, 2016). Gardner et al. (2002) used the contingent valuation method to estimate that consumers were willing to pay a retail premium of as much as \$13.35 for a flowering dogwood tree labeled as "resistant to powdery mildew." Using hypothetical conjoint analysis and nonhypothetical experimental auctions, Yue et al. (2010) found that consumers were willing to pay premiums for plants grown in biodegradable vs. plastic containers. Michaud et al. (2012) found that consumers were willing to pay an average premium of $€ 1.91$ ( $\$ 2.56$ ) per stem for roses with an eco-label and an average premium of $€ 2.51$ (\$3.36) per stem for roses claiming a carbon footprint reduction. Hartter (2012) conducted a choice experiment to estimate the premiums that consumers would be willing to pay for ornamental plants produced with WRT and labeled as "water conservation." The author found that, on average, retail consumers were willing to pay $9 \%$ to $36 \%$ more than the average retail price for Geranium, Petunia, Chrysanthemum, Azalea, Holly, and Boxwood. Behe et al. (2013) profiled nine consumer segments in terms of their preferences for local and sustainably grown plant products.

More recently, a subsequent article by Behe et al. (2014) used eye-tracking technology to categorize three plant consumer groups as plant-oriented, production methodoriented, and price-oriented. The authors found that regardless of their groups, all consumers preferred ornamental plants labeled "grown using water-saving practices" over other production labels such as "grown using energy-saving practices," "grown using sustainable practices," and "grown using conventional practices." The results also indicated that $11 \%$ of the respondents were production method-oriented among which water-saving label increased their Likert willingness to pay (WTP) scale by $\approx 6.5 \%$. Khachatryan et al. (2014) performed a mixed-logit model to estimate consumers' premiums for environmental attributes of horticulture plants, finding that individuals were willing to pay a premium for energysaving production practices $(\$ 0.13)$, nonplastic containers such as compostable (\$0.23), plantable $(\$ 0.12)$, and recyclable $(\$ 0.16)$, and locally grown plants $(\$ 0.22)$. Yue et al. (2016) investigated the U.S. consumers' WTP for sustainable attributes in plants via experimental auctions. The results showed that consumers were willing to pay a price premium for energy and water savings in plant production of $\$ 0.15$ and $\$ 0.12$ per unit, respectively, and the WTP for products labeled "sustainable" was estimated at $\$ 0.08$ per unit. These previous studies indicate that consumers are willing to pay premiums for the underlying environmental attributes of a product that promises societal benefits.

However, product labels do not completely define a product, especially in terms of environmental attributes. Usually, certifications conveyed to consumers by product labeling confirm environmental attributes. Previous research has found that consumers prefer to pay more for certified vs. uncertified products and that they generally prefer third party certification to first party or "selfcertification" (Aguilar and Vlosky, 2007; Curtis and Cowee, 2010; Hartter, 2012; Michaud et al., 2012). Hartter (2012) assumed three categories of third-party certification authorities for water conservation including governmental organizations, industry organizations, and nongovernmental organizations (NGO). Specifically, the U.S. Department of Agriculture represented the governmental organization; the American Nursery Association (a fictitious certifying authority) represented an industry-backed agency; and Water for Tomorrow and Plant Society of America represented a fictitious NGO for water conservation certification. The estimation results indicate that consumers have varying preferences and WTPs for plants certified by different authorities.

On the producer side of markets, studies of WRT adoption by horticultural growers are limited. Cultice (2013) conducted a mail survey of mid-Atlantic irrigated nursery producers to determine irrigation practices and used a conditional logit model to estimate the impacts of disease probability, drought probability, and water-recycling cost on producers' WTP to adopt water-recycling techniques and practices. Of 260 irrigated nurseries, 55\% reported that they did not capture any irrigation runoff, and only $14 \%$ captured all irrigation runoff (Cultice et al., 2016). Only six irrigated nurseries $(2.3 \%)$ sourced all their irrigation water from captured runoff. Recycling cost was the most important deterrent factor to grower adoption of water recycling (Cultice et al., 2016). Dennis et al. (2010) surveyed greenhouse and nursery crop growers nationally regarding their sustainable practices including water recycling and other water conservation measures. The authors found that $26 \%$ of their respondents had already adopted water-recycling practices, with only $4 \%$ considering future implementation of WRT. DeVincentis et al. (2015) conducted cost and benefit partial budgeting analysis of various disinfection techniques for recycled irrigation water in southern New Jersey. Disinfection methods included ultraviolet-lights, chlorinators, flooders, and drippers. The study calculated the net present value (NPV) of each disinfection technique based on site visits to five nurseries. The results indicated there was a positive correlation between system costs and the complexity of the water disinfection method. All the case nurseries had positive NPVs, indicating profitable investments. Most recently, Ferraro et al. (2017) used partial budgets to estimate and compare the annual costs of recapturing and recycling irrigation water vs. extraction costs from wells or municipal water supply sources. They found that six of eight case nurseries (all of whom had already adopted some WRT practices) had lower production costs from capturing and recycling on $75 \%$ of their production areas compared with using well or municipal water.

\section{Materials and Methods}

In this study, budgets from Ferraro et al. (2017) provide the basis for assessing producer costs of capturing and recycling. Calibrated consumer premium results are taken from Hartter (2012) as the prices that consumers would be willing to pay for plants grown with WRT. These premiums allow us to compare non-water-recycling practices (e.g., grower net returns sourcing irrigation water from municipal or private well sources) vs. returns from WRT. With adoption of WRT, changes in production costs including water-supply cost, labeling cost, and certification cost are compared with benefits from price premiums for plants labeled as "irrigation water recycled," and varying proportions are assumed to be returned to growers as compensation for the WRT investment. Hinson et al. (2012) studied market channels of ornamental plant industry and concluded that mass merchandisers have sufficient market power to affect grower prices and profitability. Retailers (e.g., "big-box" stores) could use their market power to mandate grower WRT practices while retaining some of or the entire premium for themselves. We reflect this uncertainty by varying the proportion of the premium returned to the grower $(R)$ as was done by White et al. (2014) in a study of consumer premiums for sustainable beef-production practices.

We conducted the study with eight case nurseries varying in terms of size, location, and water supply method. The eight case nurseries include three in VA (VA-1, VA-2, and VA-3), three in MD (MD-1, MD-2, and MD-3) and two in PA (PA-1 and PA-2). All eight operations are adopters of WRT as they capture rainfall and irrigation runoff in collection basins and then recycle the water to supplement water supply in addition to using municipal city water or well water. Nurseries 
VA-2, VA-3, MD-2, MD-3, and PA-2 obtain $100 \%$ of their irrigation water from recycling, and VA-1, MD-1, and PA-1 obtain 34\%, $50 \%$, and $20 \%$, respectively, from recycling. In addition, two simulated nurseries (SynSmall and SynLarge) representing mean characteristics and practices in terms of water source, grower size, and water usage are constructed based on survey responses of irrigated mid-Atlantic ornamental nurseries by Cultice et al. (2016). SynSmall represents small nurseries with gross revenues of $\$ 500,000$ or less, whereas SynLarge represents large nurseries with gross revenues greater than $\$ 500,000$. Most surveyed nurseries did not capture irrigation runoff or rainfall from any portion of their production area (Cultice, 2013), therefore, the most common alternative to WRT (well water) is assumed as the main irrigation water source for the simulated nurseries. Furthermore, we assumed the two simulated nurseries to be located in $\mathrm{MD}$, where regulations for well drilling are the most restrictive and expensive. This provides the most favorable case for adoption of WRT (Maryland Department of the Environment, 2015). Table 1 indicates the general characteristics of case study nurseries with regard to size, location, and current water supply method.

According to the 2014 Census of Horticultural Specialties (Table 2), Geraniums (Pelargonium spp.), Petunias (Petunia spp.), and Chrysanthemums (Chrysanthemum spp.) rank among the top 5 annual plants sold in VA, MD, and PA. Azaleas (Rhododendron spp.), Holly (Ilex spp.), and Boxwood (Buxus spp.) are among the top 5 broadleaf evergreen plants sold in the three states. Because of their popularity and to be consistent with premiums estimated by Hartter (2012), this analysis uses these six plants for investigating impacts of WRT adoption and consumer premiums on sales.

This study estimates enterprise-level costs and returns from WRT for each of the six plants assuming that the 10 case nurseries produce only these plants. Similar to Hartter (2012), we assume that Geraniums are sold in $10.2 \mathrm{~cm}$ (4-inch) or $0.47 \mathrm{~L}$ (0.125 gallon) pots, that Petunias are sold in 6-packs, and that Chrysanthemums are sold in $3.8 \mathrm{~L}$ (1-gallon) pots. Azaleas and Boxwoods are sold in $3.8 \mathrm{~L}$ pots with plant heights ranging from 30.5 to $38.1 \mathrm{~cm}$ (12-15 inches), and

Table 1. Size and water source of the eight case study nursery operations and two simulated nurseries.

\begin{tabular}{lrl}
\hline Nursery & Hectares & Current water supply method \\
\hline VA-1 & 1.0 & $34 \%$ recycling, $66 \%$ well \\
VA-2 & 40.5 & $100 \%$ recycling \\
VA-3 & 80.9 & $100 \%$ recycling \\
MD-1 & 6.7 & $50 \%$ recycling, $50 \%$ well \\
MD-2 & 42.5 & $100 \%$ recycling \\
MD-3 & 22.3 & $100 \%$ recycling \\
PA-1 & 2.0 & $20 \%$ recycling, $80 \%$ well \\
PA-2 & 10.9 & $100 \%$ recycling \\
SynSmall & 5.5 & $100 \%$ well water \\
SynLarge & 36.0 & $100 \%$ well water \\
\hline
\end{tabular}

Data source: Ferraro et al. (2017).

$\mathrm{MD}=$ Maryland; $\mathrm{PA}=$ Pennsylvania; $\mathrm{VA}=$ Virginia .

Hollies are sold in 7.6 L (2 gallon) pots with plant heights ranging from 38.1 to $45.7 \mathrm{~cm}$ (15-18 inches).

Because of varying container sizes, the normal production per hectare (without disease losses) differs by plant species. About 49,421-54,363 containers $3.8 \mathrm{~L}$ (1-gallon) in size will cover 1 ha of production area (Halcomb and Fare, 2009). For Geraniums planted in $10.2 \mathrm{~cm}$ (4-inch) pots, potential production is about 415,136 pots per hectare. For Petunias planted in a 6-pack, potential production per hectare is 69,189 six-packs. For Chrysanthemum, Azalea, and Boxwood planted in $3.8 \mathrm{~L}$ pots, 1 ha can produce $\approx 51,892$ pots. For Holly planted in $7.6 \mathrm{~L}$ pots, 1 ha can produce nearly 25,946 pots. In the mid-Atlantic region, commercial nurseries generally produce only one cycle of these plants per year.

The possibility of increased plant death rates with WRT must be considered. Hong and Moorman (2005) found that risk is increased as water-borne pathogens such as Pythium and Phytophthora will re-inoculate with recycled irrigation water and runoff collected from nursery production areas. To mitigate such risks, growers typically treat recycled irrigation water with sterilizers such as liquid or gas chlorination systems. In the survey conducted by Cultice (2013), the average proportion of nursery revenue loss in sales from all types of plant disease (i.e., plant death rate) for both non-water recyclers and water recyclers was reported. On average, plant death rates for non-adopters and adopters of WRT were estimated at $2 \%$ and $3 \%$, respectively. Based on the mean survey responses, this analysis assumes that plant death rate will increase to $3 \%$ because of diseases caused by water-borne pathogens after adoption of WRT compared with $2 \%$ for non-adoption of WRT. Thus, for the case nurseries and the two hypothetical nurseries, the reduced production per hectare resulting from converting to recycling for each of the six plants is assumed the same, which can be expressed as

$$
\Delta Y_{i}=Y_{i}(-1 \%)
$$

where $Y_{i}$ is normal production cost per hectare of the six plants without disease losses as stated previously and $-1 \%$ indicates the reduction in yield resulting from a switch to WRT. Because the yield losses lead to growers' sales losses, the opportunity cost of yield loss resulting from adoption of WRT for plant type $i$ can be expressed as

$$
\mathrm{OP}_{i}=-\Delta Y_{i} P_{i}^{\mathrm{w}}
$$

where $P_{i}^{\mathrm{w}}$ is the wholesale price accepted by growers of plant $i$.

The change in production cost resulting from water recycling for plant $i, \Delta P C_{i}$, is

$$
\Delta \mathrm{PC}_{i}=\Delta \mathrm{WSC}_{i}+\Delta \mathrm{LC}_{i}+\Delta \mathrm{CC}_{i}
$$

where $\Delta \mathrm{WSC}_{i}$ is water supply cost change, $\Delta \mathrm{LC}_{i}$ is labeling cost change, and $\Delta \mathrm{CC}_{i}$ is certification cost change. Water supply cost change results from the change in cost of delivering irrigation water to the crop as a result of switching to WRT. Labeling cost change accounts for a change in cost of labeling individual pots resulting from yield changes. Certification cost change accounts for the cost of hiring a third-party contractor to certify that advertised plants receive water from WRT practices. These costs are described in the following paragraphs.

Ferraro et al. (2017) used partial budgets to evaluate water supply cost changes from adoption of recycling for the case nurseries. They analyzed differences in practices and associated costs for recycling in comparison with the next best option (well water or municipal water). Capital costs for both conventional water supply (well or municipal source) and WRT were amortized on an annual basis; thus $\Delta \mathrm{WSC}_{i}$ refers to annual water-supply cost change. Partial budget results in 2014 dollars from Ferraro et al. (2017) are presented in Table $3 . \Delta \mathrm{WSC}_{i}$ is the difference between WRT cost and the cost of the next best alternative; thus, a negative $\Delta \mathrm{WSC}_{i}$ refers to a cost advantage with WRT and vice versa. WRT costs vary among nurseries depending on physical layout, distance to water source, and other factors. Nurseries VA-1, VA-2, VA-3, MD-1, MD2 , and PA-1 have cost advantages with WRT of $-\$ 1624 / \mathrm{ha},-\$ 29,910 / \mathrm{ha},-\$ 6339 / \mathrm{ha}$, $-\$ 813 / \mathrm{ha},-\$ 2851 / \mathrm{ha}$, and $-\$ 343 / \mathrm{ha}$, respectively. As discussed in Ferraro et al. (2017), the major factors determining cost advantage per hectare from WRT are the availability and cost of the alternative well or municipal water source and the costs of WRT investment. For example, VA-2 saves more costs with WRT than VA-1 because of much higher costs of obtaining municipal water. WRT costs are also highly variable among nurseries because of differences in the cost of digging recapture ponds, opportunity cost (forgone income) of land used for ponds, and regrading cost.

Nurseries MD-3 and PA-2 incur increased costs with WRT, estimated at $\$ 7516 /$ ha and $\$ 2199 /$ ha, respectively (Table 3). For the two simulated nurseries SynSmall and SynLarge, that are assumed to use well water as the main irrigation water supply, WRT increased water supply costs by an estimated $\$ 3810 /$ ha and \$7651/ha, respectively.

Certification is necessary to assure consumers of the attribute associated with paying a premium. However, there are no industry-wide 
Table 2. Sales and percent of total U.S. sales of six horticultural plants by state in 2014.

\begin{tabular}{|c|c|c|c|c|c|c|c|c|c|}
\hline & \multicolumn{3}{|c|}{ Geranium } & \multicolumn{3}{|c|}{ Petunia } & \multicolumn{3}{|c|}{ Chrysanthemum } \\
\hline & VA & MD & PA & VA & MD & PA & VA & MD & PA \\
\hline \multirow[t]{2}{*}{ Wholesale $(\$ 1,000)$} & 6,773 & 1,112 & 5,585 & 6,253 & 1,594 & 1,077 & 7,204 & $\mathrm{~N} / \mathrm{A}$ & 2,485 \\
\hline & $6.0 \%$ & $1.0 \%$ & $4.9 \%$ & $9.8 \%$ & $2.5 \%$ & $1.7 \%$ & $15.2 \%$ & $\mathrm{~N} / \mathrm{A}$ & $5.3 \%$ \\
\hline \multirow[t]{2}{*}{ Retail $(\$ 1,000)$} & 854 & 326 & 3,185 & 260 & 200 & 857 & 47 & $\mathrm{~N} / \mathrm{A}$ & 207 \\
\hline & $1.7 \%$ & $0.6 \%$ & $6.2 \%$ & $1.6 \%$ & $1.2 \%$ & $5.4 \%$ & $1.3 \%$ & N/A & $5.7 \%$ \\
\hline \multirow[t]{4}{*}{ Total $(\$ 1,000)$} & 7,627 & 1,438 & 8,770 & 6,513 & 1,794 & 1,934 & 7,251 & 25 & 2,692 \\
\hline & $4.6 \%$ & $0.9 \%$ & $5.3 \%$ & $8.2 \%$ & $2.2 \%$ & $2.4 \%$ & $14.2 \%$ & $0.05 \%$ & $5.3 \%$ \\
\hline & \multicolumn{3}{|c|}{ Azalea } & \multicolumn{3}{|c|}{ Holly } & \multicolumn{3}{|c|}{ Boxwood } \\
\hline & VA & MD & PA & VA & MD & PA & $\mathrm{VA}$ & MD & PA \\
\hline \multirow[t]{2}{*}{ Wholesale $(\$ 1,000)$} & 3,323 & 1,615 & 359 & 8,528 & 12,651 & 759 & 5,611 & 8,852 & 1,775 \\
\hline & $3.8 \%$ & $1.8 \%$ & $0.4 \%$ & $7.3 \%$ & $10.8 \%$ & $0.6 \%$ & $4.8 \%$ & $7.5 \%$ & $1.5 \%$ \\
\hline \multirow[t]{2}{*}{ Retail $(\$ 1,000)$} & 36 & 75 & 105 & 91 & 256 & 248 & 36 & 14 & 429 \\
\hline & $0.8 \%$ & $1.6 \%$ & $2.3 \%$ & $1.6 \%$ & $4.4 \%$ & $4.2 \%$ & $0.4 \%$ & $0.2 \%$ & $5.2 \%$ \\
\hline \multirow[t]{2}{*}{ Total $(\$ 1,000)$} & 3,359 & 1,690 & 464 & 8,619 & 12,907 & 1,007 & 5,647 & 8,866 & 2,204 \\
\hline & $3.6 \%$ & $1.8 \%$ & $0.5 \%$ & $7.0 \%$ & $10.5 \%$ & $0.8 \%$ & $4.5 \%$ & $7.0 \%$ & $1.7 \%$ \\
\hline
\end{tabular}

Note: The percentage number placed under each sale volume represents each state's share of U.S. Retail/Wholesale/Total sales for each type of the six plants. Data source: U.S. Department of Agriculture, National Agricultural Statistics Service (2014).

$\mathrm{MD}=$ Maryland; PA = Pennsylvania; VA = Virginia.

Table 3. Net water supply cost changes for eight nursery operations (VA-1 to PA-2) and two simulated nurseries (SynSmall and SynLarge) with alternative water sources.

\begin{tabular}{|c|c|c|c|c|c|}
\hline Nursery & Alternative & More profitable option & WRT cost (\$/ha) & Alternative cost $(\$ /$ ha $)$ & Water supply cost change with WRT (\$/ha) \\
\hline$\overline{\mathrm{VA}-1}$ & Municipal water & WRT & 4,400 & 6,024 & $-1,624$ \\
\hline VA-2 & Municipal water & WRT & 4,817 & 34,728 & $-29,910$ \\
\hline VA-3 & Municipal water & WRT & 5,874 & 12,213 & $-6,339$ \\
\hline MD-1 & Well water & WRT & 650 & 1,463 & -813 \\
\hline MD-2 & Municipal water & WRT & 3,770 & 6,621 & $-2,851$ \\
\hline MD-3 & Well water & Well water & 7,923 & 406 & 7,516 \\
\hline PA-1 & Well water & WRT & 26,967 & 27,310 & -343 \\
\hline PA-2 & Municipal water & Municipal water & 4,242 & 2,044 & 2,199 \\
\hline SynSmall & Well water & Well water & 5,956 & 2,146 & 3,810 \\
\hline SynLarge & Well water & Well water & 9,035 & 1,384 & 7,651 \\
\hline
\end{tabular}

Data source: Ferraro et al. (2017).

$\mathrm{MD}=$ Maryland; PA = Pennsylvania $; \mathrm{VA}=$ Virginia; WRT = Water-recycling technology .

certification systems to define production with recycled irrigation water. It is assumed that producers who wish to increase net returns with recycling would contract a qualified and respected third party to certify that their operation practices and nursery products accord with specific standards of WRT. Such standards would specify minimum requirements as to how water is recycled to ensure that the environmental benefits of recycling are achieved. After certification, producers are authorized to label plants as "produced with recycled water," whereby consumers can acquire environmental information that may influence their preferences and WTP for horticultural products.

Labeling cost and certification costs also relate to the documentation of cost changes in water-supply practices resulting from recycling. Based on the information provided by the owners and managers of the case nurseries during onsite interviews, the unit labeling cost is about $\$ 0.10 /$ pot. Thus, a labeling cost change is

$$
\Delta \mathrm{LC}_{i}=0.1 \Delta Y_{i}
$$

where $\Delta \mathrm{LC}_{i}$ is the labeling cost change, and $\Delta Y_{i}$ is the net negative change of normal production per hectare for recyclers specified in Eq. [1]. The labeling cost associated with WRT in Eq. [4] is negative because of the yield loss from increased plant death rate.

The example cost data for certification is developed from the "Sustainability Standard for Nursery and Greenhouse Operations" operated by Food Alliance, a nonprofit organization that has certified over 330 farms, ranches, and food processors in Canada, Mexico, and 23 U.S. states for good environmental stewardship. Although the organization does not have an independent certification program focusing on water recycling for the nursery industry, the sustainability standard does contain specific criteria for water conservation and recycled water quality in nursery operations. The Food Alliance publishes detailed certification costs on its website that are used in this analysis. The certification costs consist of an inspection fee and a license fee. The inspection fee includes a nonrefundable $\$ 350$ document processing charge and a $\$ 400$ deposit toward the actual cost of inspection. According to Food Alliance, in most cases, the average inspection fee is between $\$ 900$ and $\$ 1500$. Because Food Alliance certification is valid for 3 years, the average annual inspection fee ranges from $\$ 300$ to $\$ 500$ per year. In addition, nursery operations pay a variable annual license fee based on a percentage of gross annual sales ( $\$ 100$ flat fee less than $\$ 100,000,0.10 \%$ from $\$ 100,000$ to $\$ 1,000,000$, and $0.05 \%$ greater than $\$ 1,000,000)$, with a licensing fee cap of $\$ 5000$. For example, gross revenue for nursery MD-2 reported in the survey is $\$ 7,000,000$; thus, the annual license fee would be $\$ 3500$. After adding the maximum average annual inspection fee of $\$ 500$, the average annual certification cost would be $\approx \$ 94 /$ ha $(\$ 94 / \mathrm{ha}[\$ 3500+\$ 500] / 42.5 \mathrm{ha})$. Errors in estimating certification costs are unlikely to affect final results because in three-fourths of the cases (Tables $4-7$ ), the certification cost is $3 \%$ or less of the total production cost change.

For this analysis, it is assumed that in a typical wholesale nursery production contract, retailers offer price premiums to encourage contract growers to produce plants with WRT. Following Cultice (2013), $\approx 52 \%$ of growers are wholesalers. Thus, a conservative assumption in this analysis is that the case nurseries are wholesalers who sell all plants directly to retailers, who in turn sell to consumers and return a portion of the premium to growers. If growers were retailers, they would retain all of the premium. Equation [5] clarifies how price premiums tied to WRT plants could be returned proportionally to growers and increase gross revenue.

$$
\begin{aligned}
& \Delta \mathrm{GR}_{i}=\mathrm{GR}_{i}^{\mathrm{WRT}}-\mathrm{GR}_{i}^{\mathrm{Non}-\mathrm{WRT}} \\
& =Y_{i}(100 \%-3 \%) P_{i}^{\mathrm{W}}-Y_{i}(100 \%-2 \%) P_{i}^{\mathrm{W}} \\
& =0.97 Y_{i} \cdot\left(P_{i}^{\mathrm{w}}+\mathrm{WTP} \cdot R\right)-0.98 Y_{i} P_{i}^{\mathrm{W}} \\
& =\Delta Y_{i} \cdot P_{i}^{\mathrm{W}}+0.97 \cdot Y_{i} \cdot \mathrm{WTP} \cdot R
\end{aligned}
$$

where $P_{i}^{\mathrm{w} \prime}=P_{i}^{\mathrm{w}}+\mathrm{WTP} R$ is the new wholesale price after adding a proportional premium (denoted as WTP), in which $R$ is a conveyance rate indicating the fraction of 
Table 4. Labeling cost change $\left(\Delta \mathrm{LC}_{i}\right)$, certification cost change $\left(\Delta \mathrm{CC}_{i}\right)$, and production cost change $\left(\Delta \mathrm{PC}_{i}\right)$ with water recycling technology for Geranium.

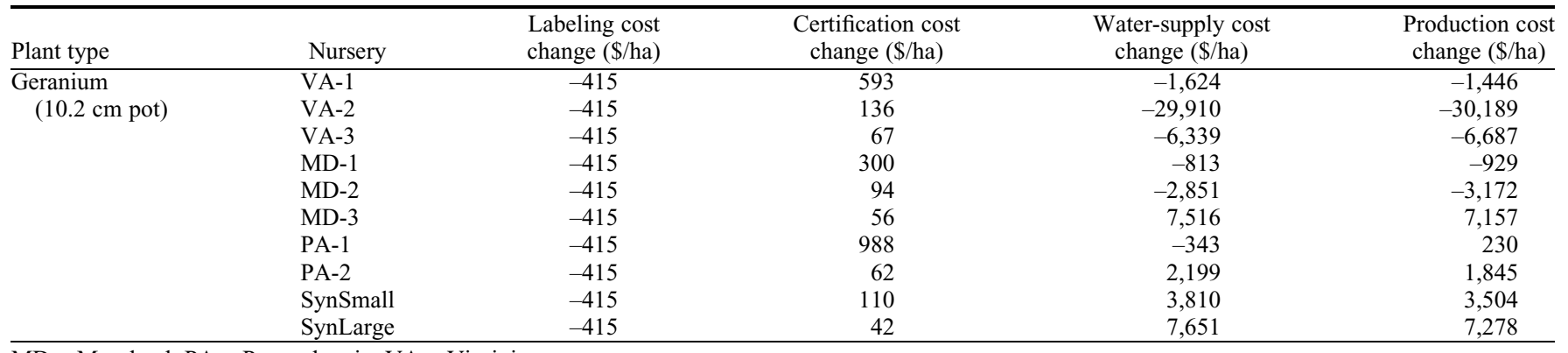

$\mathrm{MD}=$ Maryland; PA = Pennsylvania; VA = Virginia.

Table 5. Labeling cost changes $\left(\Delta \mathrm{LC}_{i}\right)$, certification cost changes $\left(\Delta \mathrm{CC}_{i}\right)$, and production cost changes $\left(\Delta \mathrm{PC}_{i}\right)$ with water recycling technology for Petunia.

\begin{tabular}{|c|c|c|c|c|c|}
\hline Plant type & Nursery & $\begin{array}{l}\text { Labeling cost } \\
\text { change (\$/ha) }\end{array}$ & $\begin{array}{c}\text { Certification cost } \\
\text { change }(\$ / \mathrm{ha})\end{array}$ & $\begin{array}{c}\text { Water-supply cost } \\
\text { change }(\$ / h a)\end{array}$ & $\begin{array}{c}\text { Production cost } \\
\text { change (\$/ha) }\end{array}$ \\
\hline & VA-2 & -69 & 136 & $-29,910$ & $-29,843$ \\
\hline & VA-3 & -69 & 67 & $-6,339$ & $-6,341$ \\
\hline & MD-2 & -69 & 94 & $-2,851$ & $-2,826$ \\
\hline & MD-3 & -69 & 56 & 7,516 & 7,503 \\
\hline & PA-1 & -69 & 988 & -343 & 576 \\
\hline & SynLarge & -69 & 42 & 7,651 & 7,624 \\
\hline
\end{tabular}

$\mathrm{MD}=$ Maryland; PA = Pennsylvania; VA = Virginia.

Table 6. Labeling cost changes $\left(\Delta \mathrm{LC}_{i}\right)$, certification cost changes $\left(\Delta \mathrm{CC}_{i}\right)$, and production cost changes $(\Delta \mathrm{PC})$ with water recycling technology for Chrysanthemum, Azalea, and Boxwood.

\begin{tabular}{|c|c|c|c|c|c|}
\hline Plant type & Nursery & $\begin{array}{l}\text { Labeling cost } \\
\text { change }(\$ / \mathrm{ha})\end{array}$ & $\begin{array}{l}\text { Certification cost } \\
\text { change }(\$ / \text { ha })\end{array}$ & $\begin{array}{c}\text { Water-supply cost } \\
\text { change }(\$ / \mathrm{ha})\end{array}$ & $\begin{array}{l}\text { Production cost } \\
\text { change }(\$ / \mathrm{ha})\end{array}$ \\
\hline Boxwood $(3.8 \mathrm{~L}$ pot $)$ & VA-2 & -52 & 136 & $-29,910$ & $-29,826$ \\
\hline & VA-3 & -52 & 67 & $-6,339$ & $-6,324$ \\
\hline & MD-2 & -52 & 94 & $-2,851$ & $-2,809$ \\
\hline & MD-3 & -52 & 56 & 7,516 & 7,521 \\
\hline & PA-1 & -52 & 988 & -343 & 594 \\
\hline
\end{tabular}

$\mathrm{MD}=$ Maryland; PA = Pennsylvania; VA = Virginia.

Table 7. Labeling cost change $\left(\Delta \mathrm{LC}_{i}\right)$, certification cost change $\left(\Delta \mathrm{CC}_{i}\right)$, and production cost change $\left(\Delta \mathrm{PC}_{i}\right)$ with water recycling technology for Holly.

\begin{tabular}{|c|c|c|c|c|c|}
\hline Plant type & Nursery & $\begin{array}{l}\text { Labeling cost } \\
\text { change }(\$ / \mathrm{ha})\end{array}$ & $\begin{array}{l}\text { Certification cost } \\
\text { change }(\$ / \mathrm{ha})\end{array}$ & $\begin{array}{l}\text { Water-supply cost } \\
\text { change (\$/ha) }\end{array}$ & $\begin{array}{l}\text { Production cost } \\
\text { change }(\$ / \text { ha })\end{array}$ \\
\hline & VA-2 & -26 & 136 & $-29,910$ & $-29,800$ \\
\hline & VA-3 & -26 & 67 & $-6,339$ & $-6,298$ \\
\hline & MD-2 & -26 & 94 & $-2,851$ & $-2,783$ \\
\hline & MD-3 & -26 & 56 & 7,516 & 7,546 \\
\hline & PA-1 & -26 & 988 & -343 & 619 \\
\hline & SynLarge & -26 & 42 & 7,651 & 7,667 \\
\hline
\end{tabular}

$\mathrm{MD}=$ Maryland; $\mathrm{PA}=$ Pennsylvania; $\mathrm{VA}=$ Virginia

the consumer premium being returned to the water-recycling nursery. After readjusting, $\Delta Y_{i} \cdot P_{i}^{\mathrm{w}}$ refers to the gross revenue loss from WRT because of yield loss, whereas $0.97 \cdot Y_{i}$.WTP. $R$ is the increased gross revenue resulting from consumer premiums for plants grown with WRT.

Premium estimates obtained from growers by Hartter (2012) are based on survey responses to a hypothetical choice experiment. However, hypothetical responses may suffer from "hypothetical bias," i.e., overstating consumer WTP compared with revealed choices of consumers with actual purchases in non-hypothetical situations (Blumenschein et al., 2008; Cummings et al., 1995; Harrison, 2006; Harrison and Rutström, 2008; List and Gallet, 2001; Silva et al., 2007; Yue et al., 2010). For example, List and Gallet (2001) summarized 29 experimental studies and concluded that respondents on average overestimated their preferences by a factor of 3 in hypothetical settings compared with actual purchases. Silva et al. (2007) found that on average, the non-hypothetical estimates of WTP estimates for different groups of novel 
products were from $8 \%$ to $29 \%$ lower than the hypothetical WTP estimates in two elicitation mechanisms including experimental auction and conjoint analysis. Blumenschein et al. (2008) concluded that the average WTP for a pharmacist-provided diabetes program in a real purchasing group was $50 \%$ lower than that obtained in hypothetical surveys. Yue et al. (2010) found that the mean WTP for plant containers made from rice hulls (straw) obtained from an experimental auction was $29 \%$ (39\%) lower than that obtained from a hypothetical conjoint analysis. Although Hartter (2012) applied a "cheap talk" method as suggested by Cummings and Taylor (1999) to reduce hypothetical bias and the potential for artificially high WTP estimates, premium estimates are calibrated (divided by 3 ) as suggested by List and Gallet (2001).

The horticultural plant price data $P_{i}^{\mathrm{w}}$ (wholesale) and $P_{i}^{\mathrm{r}}$ (retail) is obtained from the Census of Horticultural Specialties (USDA/NASS, 2014). The calibrated (divided by 3) mean values of estimated premiums by Hartter (2012) are shown with 2014 census prices in Tables 8 and 9 after adjustment to 2014 dollars using the consumer price index of indoor plants and flowers (U.S. Bureau of Labor Statistics, 2015).

Finally, the net revenue change from recycling $\left(\Delta \mathrm{NR}_{\mathrm{i}}\right)$ is the difference between gross revenue change and production cost change:

$$
\Delta \mathrm{NR}_{i}=\Delta \mathrm{GR}_{i}-\Delta \mathrm{PC}_{i}
$$

where $\Delta \mathrm{GR}_{i}$ is the gross revenue change calculated with Eq. [5] and $\Delta \mathrm{PC}_{i}$ is the production cost change calculated with Eq. [3].

The sensitivity of gross and net revenue changes to the conveyance rate $(R)$ is evaluated with the premium estimate fixed at its mean value. Three possible $R$ values are selected: $0 \%, P_{i}^{\mathrm{w}} / P_{i}^{\mathrm{r}}$, and $100 \%$. Zero percent is a pessimistic value at which the grower receives nothing from the consumer premiums; $P_{i}^{\mathrm{w}} / P_{i}^{\mathrm{r}}$ is the census price ratio of wholesale price and retail price of each plant in Tables 8 and 9; and $100 \%$ is an optimistic value at which the grower receives the complete premium. Where price ratios $P_{i}^{\mathrm{w}} / P_{i}^{\mathrm{r}}$ exceed $100 \%$, such as Azalea in PA, Holly in MD, and Boxwood in VA and MD, $100 \%$ is used. In addition, break-even analyses to balance production cost and gross revenue change associated with WRT (i.e., $\left.\Delta \mathrm{NR}_{i}=0\right)$ are conducted in terms of conveyance rate $R$, premium estimate and plant death rate.

\section{Results}

Production cost changes. Labeling cost changes, certification cost changes and production cost changes resulting from WRT are presented in Tables 4-7. For each of the six plants, nurseries VA-1, VA-2, VA-3, MD-1, and MD-2 have lower production costs with WRT compared with well water or municipal water as the reduced labeling cost and water supply cost more than offset the certification cost in each case. For nurseries MD-3, PA-1, and PA-2 and for the two simulated nurseries SynSmall and SynLarge, the production costs of WRT are higher than using well water or municipal water. Production costs increase for MD-3, PA-2, SynSmall, and SynLarge because of large water supply cost increases ranging from $\$ 2199$ to $\$ 7651$ per hectare. WRT reduces water supply costs for PA-1; however, production costs increase modestly because of the certification cost ( $\$ 988 / \mathrm{ha} /$ year). The high certification cost for PA-1 is mainly because of its reported high per hectare gross revenue $(\approx \$ 241,915 / \mathrm{ha})$, much higher than other nurseries.

Gross revenue changes with WRT. Table 10 shows the estimated changes in gross revenues by plant species with alternative conveyance rates. $Y_{i}$ and $\Delta Y_{i}$ are held constant for all nurseries, therefore, changes of gross revenues resulting from different wholesale prices garnered by each nursery operation are based on its geographic location. SynSmall and SynLarge are assumed located in $\mathrm{MD}$, so their gross revenue changes match those of MD case nurseries. When no premiums go back to growers (conveyance rate $R=0 \%$ ), all nurseries have negative gross revenue changes for each of the six plants because of the assumed increased plant death rate with WRT. When the conveyance rate is $100 \%$ (growers obtain all the premium) and when $R=P_{i}^{\mathrm{w}} / P_{i}^{\mathrm{r}}$, all 10 nurseries have positive changes in gross revenue for five plants with Holly as an exception. For Holly, the nurseries in VA have decreased gross revenues at $-\$ 1098 /$ ha when $R=P_{i}^{\mathrm{w}} / P_{i}^{\mathrm{r}}$; the nurseries in MD as well as the synthetic nurseries have negative gross revenue changes estimated at $-\$ 219 /$ ha when $R=P_{i}^{\mathrm{w}} / P_{i}^{\mathrm{r}}$ or $R=100 \%$.

Net revenue changes with WRT. After deducting production cost changes from the gross revenue changes, the net revenue changes for alternative conveyance rates are shown in Tables 11 and 12. In the cases of Azalea in PA, Holly in MD, and Boxwood in $\mathrm{VA}$ and $\mathrm{MD}$, the wholesale price $\left(P_{i}^{\mathrm{w}}\right)$ is greater than the retail price $\left(P_{i}^{r}\right)$ reported in the Census as shown in Tables 8 and 9. In those cases, $P_{i}^{\mathrm{w}}$ is assumed equal to $P_{i}^{\mathrm{r}}$ resulting in the same gross revenue change as obtained for $R=100 \%$.

When the conveyance rate $R$ is $0 \%$, only nursery VA-2 has increased net revenue for all plants because of its large production cost saving from WRT that fully offsets the opportunity cost of yield loss. For nursery VA-1, only Petunia generates a positive net revenue change of $\$ 291 /$ ha. Nursery VA-3 has increased net revenues for all plants except Geranium (-\$1034/ha) and Boxwood $(-\$ 6561 / \mathrm{ha})$ as its production cost savings for these two plants fail to cover the opportunity cost of yield loss. MD-2 has relatively small positive net revenue changes for Petunia (\$1899/ha) and Chrysanthemum (\$157/ha).

Table 8. Calibrated premiums and wholesale and retail prices of three annual bedding plants by states, adjusted to 2014 dollars.

\begin{tabular}{lcccccc}
\hline & Premiums & & \multicolumn{3}{c}{ Prices by state } \\
\cline { 2 - 6 } Plant type $i$ & Mean & & State & $P_{i}^{\mathrm{w}}$ & $P_{i}^{\mathrm{r}}$ & $P_{i}^{\mathrm{w}} / P_{i}^{\mathrm{r}}$ \\
\hline Geranium (\$/10.2 cm pot) & 0.52 & & VA & 1.86 & 2.69 & 0.69 \\
& & & MD & 2.06 & 3.46 & 0.59 \\
Petunia (\$/6-pack) & \multirow{2}{*}{0.33} & PA & 1.79 & 2.93 & 0.61 \\
& & VA & 1.17 & 3.12 & 0.38 \\
Chrysanthemum (\$/3.8 L pot) & & MD & 1.34 & 2.67 & 0.50 \\
& \multirow{2}{*}{0.46} & PA & 1.20 & 2.76 & 0.44 \\
& & VA & 3.59 & 5.88 & 0.61 \\
& & MD & 5.11 & 5.11 & 1.00 \\
& & PA & 3.72 & 5.77 & 0.64 \\
\hline
\end{tabular}

Note: Wholesale and retail prices for Chrysanthemum in MD are not available, so the wholesale and retail prices are both equal to total sale value divided by total number sold.

Data sources: Hartter (2012) and U.S. Department of Agriculture, National Agricultural Statistics Service (2014).

$\mathrm{MD}=$ Maryland $\mathrm{PA}=$ Pennsylvania $; \mathrm{VA}=$ Virginia .

Table 9. Calibrated premiums and wholesale and retail prices of broadleaf evergreen plants by states, adjusted to 2014 dollars.

\begin{tabular}{|c|c|c|c|c|c|}
\hline \multirow[b]{2}{*}{ Plant type $i$} & \multirow{2}{*}{$\frac{\text { Premiums }}{\text { Mean }}$} & \multicolumn{4}{|c|}{ Prices by state } \\
\hline & & State & $P_{i}^{\mathrm{W}}$ & $P_{i}^{\mathrm{r}}$ & $P_{i}^{\mathrm{w}} / P_{i}^{\mathrm{r}}$ \\
\hline \multirow[t]{3}{*}{ Azalea (\$/13.8 L pot) } & 0.43 & $\mathrm{VA}$ & 8.95 & 12.44 & 0.72 \\
\hline & & MD & 10.99 & 20.13 & 0.55 \\
\hline & & PA & 18.91 & 13.04 & 1.45 \\
\hline \multirow[t]{3}{*}{ Holly (\$/3.8 L pot) } & 0.34 & VA & 13.50 & 47.57 & 0.28 \\
\hline & & MD & 33.50 & 21.83 & 1.53 \\
\hline & & PA & 23.48 & 31.55 & 0.74 \\
\hline \multirow[t]{3}{*}{ Boxwood $(\$ / 3.8 \mathrm{~L}$ pot $)$} & 0.60 & VA & 24.83 & 24.42 & 1.02 \\
\hline & & MD & 25.65 & 16.00 & 1.60 \\
\hline & & PA & 16.65 & 23.20 & 0.72 \\
\hline
\end{tabular}

Data sources: Hartter (2012) and U.S. Department of Agriculture, National Agricultural Statistics Service (2014).

$\mathrm{MD}=$ Maryland PA $=$ Pennsylvania $; \mathrm{VA}=$ Virginia . 


\begin{tabular}{|c|c|c|c|c|c|c|}
\hline \multirow[b]{4}{*}{ Nursery type } & \multicolumn{6}{|c|}{ Gross revenue changes under alternative $R$ values (\$/ha) } \\
\hline & $R=0 \%$ & $R=P_{i}^{\mathrm{w}} / P_{i}^{\mathrm{r}}$ & $R=100 \%$ & $R=0 \%$ & $R=P_{i}^{\mathrm{w}} / P_{i}^{\mathrm{r}}$ & $R=100 \%$ \\
\hline & \multicolumn{3}{|c|}{ Annual bedding plants } & \multicolumn{3}{|c|}{ Broadleaf evergreen plants } \\
\hline & \multicolumn{3}{|c|}{ Geranium } & \multicolumn{3}{|c|}{ Azalea } \\
\hline $\mathrm{VA}(1,2,3)$ & $-7,722$ & 136,136 & 200,331 & $-4,644$ & 11,048 & 17,168 \\
\hline $\operatorname{MD}(1,2,3)$ & $-8,552$ & 115,318 & 199,501 & $-5,703$ & 6,205 & 16,109 \\
\hline $\mathrm{PA}(1,2)$ & $-7,431$ & 119,673 & 200,622 & $-9,813$ & 11,999 & 11,999 \\
\hline Syn (Small, Large) & \multicolumn{3}{|c|}{ Petunia } & \multicolumn{2}{|r|}{ Holly } & 16,109 \\
\hline$\overline{\mathrm{VA}(1,2,3)}$ & -810 & 7,580 & 21,562 & $-3,503$ & $-1,098$ & 4,970 \\
\hline $\operatorname{MD}(1,2,3)$ & -927 & 10,300 & 21,444 & $-8,692$ & -219 & -219 \\
\hline $\mathrm{PA}(1,2)$ & -830 & 8,896 & 21,541 & $-6,092$ & 214 & 2,381 \\
\hline Syn (Small, Large) & \multicolumn{3}{|c|}{ Chrysanthemum } & \multicolumn{3}{|c|}{ Boxwood } \\
\hline$\overline{\mathrm{VA}(1,2,3)}$ & $-1,863$ & 12,274 & 21,291 & $-12,885$ & 17,484 & 17,484 \\
\hline $\operatorname{MD}(1,2,3)$ & $-2,652$ & 20,503 & 20,503 & $-13,310$ & 17,059 & 17,059 \\
\hline $\operatorname{PA}(1,2)$ & $-1,930$ & 12,997 & 21,224 & $-8,640$ & 13,155 & 21,729 \\
\hline Syn (Small, Large) & $-2,652$ & 20,503 & 20,503 & $-13,310$ & 17,059 & 17,059 \\
\hline
\end{tabular}

Note: The two simulated nurseries are assumed located in MD, thus the results for Syn (Small, Large) and MD (1, 2, 3) are always equal in this table.

$\mathrm{MD}=$ Maryland; PA = Pennsylvania; VA = Virginia.

Table 11 . Net revenue sensitivity $\left(\Delta \mathrm{NR}_{i}\right)$ to conveyance rates $(R)$ for three annual bedding plants.

\begin{tabular}{|c|c|c|c|c|c|c|c|c|c|}
\hline \multirow[b]{3}{*}{ Nursery } & \multicolumn{9}{|c|}{ Net revenue changes under different $R$ values $(\$ /$ ha) } \\
\hline & $R=0 \%$ & $R=P_{i}^{\mathrm{W}} / P_{i}^{\mathrm{r}}$ & $R=100 \%$ & $R=0 \%$ & $R=P_{i}^{\mathrm{w}} / P_{i}^{\mathrm{r}}$ & $R=100 \%$ & $R=0 \%$ & $R=P_{i}^{\mathrm{W}} / P_{i}^{\mathrm{r}}$ & $R=100 \%$ \\
\hline & \multicolumn{3}{|c|}{ Geranium } & \multicolumn{3}{|c|}{ Petunia } & \multicolumn{3}{|c|}{ Chrysanthemum } \\
\hline$\overline{\mathrm{VA}-1}$ & $-6,275$ & 137,582 & 201,777 & 291 & 8,680 & 22,662 & -780 & 13,357 & 22,374 \\
\hline VA-2 & 22,468 & 166,326 & 230,520 & 29,034 & 37,423 & 51,405 & 27,963 & 42,100 & 51,117 \\
\hline VA-3 & $-1,034$ & 142,824 & 207,018 & 5,532 & 13,921 & 27,903 & 4,461 & 18,598 & 27,615 \\
\hline MD-1 & $-7,623$ & 116,247 & 200,430 & -344 & 10,883 & 22,027 & $-2,086$ & 21,068 & 21,068 \\
\hline MD-2 & $-5,380$ & 118,490 & 202,673 & 1,899 & 13,127 & 24,270 & 157 & 23,312 & 23,312 \\
\hline MD-3 & $-15,709$ & 108,160 & 192,343 & $-8,430$ & 2,797 & 13,941 & $-10,172$ & 12,982 & 12,982 \\
\hline PA-1 & $-7,661$ & 119,443 & 200,391 & $-1,407$ & 8,320 & 20,965 & $-2,524$ & 12,404 & 20,630 \\
\hline PA-2 & $-9,276$ & 117,828 & 198,776 & $-3,021$ & 6,705 & 19,350 & $-4,139$ & 10,789 & 19,015 \\
\hline SynSmall & $-12,056$ & 111,813 & 195,996 & $-4,778$ & 6,450 & 17,594 & $-6,519$ & 16,635 & 16,635 \\
\hline SynLarge & $-15,830$ & 108,040 & 192,223 & $-8,551$ & 2,676 & 13,820 & $-10,293$ & 12,861 & 12,861 \\
\hline
\end{tabular}

$\mathrm{MD}=$ Maryland; $\mathrm{PA}=$ Pennsylvania; $\mathrm{VA}=$ Virginia.

Table 12 . Net revenue sensitivity $\left(\Delta \mathrm{NR}_{i}\right)$ to conveyance rates $(R)$ for three broadleaf evergreen plants.

\begin{tabular}{|c|c|c|c|c|c|c|c|c|c|}
\hline \multirow[b]{3}{*}{ Nursery } & \multicolumn{9}{|c|}{ Net revenue changes under different $R$ values $(\$ /$ ha) } \\
\hline & $R=0 \%$ & $R=P_{i}^{\mathrm{w}} / P_{i}^{\mathrm{r}}$ & $R=100 \%$ & $R=0 \%$ & $R=P_{i}^{\mathrm{w}} / P_{i}^{\mathrm{r}}$ & $R=100 \%$ & $R=0 \%$ & $R=P_{i}^{\mathrm{W}} / P_{i}^{\mathrm{r}}$ & $R=100 \%$ \\
\hline & \multicolumn{3}{|c|}{ Azalea } & \multicolumn{3}{|c|}{ Holly } & \multicolumn{3}{|c|}{ Boxwood } \\
\hline$\overline{\text { VA-1 }}$ & $-3,562$ & 12,131 & 18,250 & $-2,446$ & -41 & 6,027 & $-11,802$ & 18,567 & 18,567 \\
\hline VA-2 & 25,182 & 40,875 & 46,994 & 26,298 & 28,702 & 34,771 & 16,941 & 47,310 & 47,310 \\
\hline VA-3 & 1,680 & 17,372 & 23,492 & 2,795 & 5,200 & 11,269 & $-6,561$ & 23,808 & 23,808 \\
\hline MD-1 & $-5,137$ & 6,771 & 16,675 & $-8,152$ & 321 & 321 & $-12,745$ & 17,624 & 17,624 \\
\hline MD-2 & $-2,894$ & 9,014 & 18,918 & $-5,909$ & 2,564 & 2,564 & $-10,501$ & 19,868 & 19,868 \\
\hline MD-3 & $-13,223$ & $-1,315$ & 8,588 & $-16,238$ & $-7,765$ & $-7,765$ & $-20,831$ & 9,538 & 9,538 \\
\hline PA-1 & $-10,406$ & 11,406 & 11,406 & $-6,712$ & -406 & 1,761 & $-9,234$ & 12,561 & 21,135 \\
\hline PA-2 & $-12,021$ & 9,791 & 9,791 & $-8,327$ & $-2,021$ & 147 & $-10,849$ & 10,946 & 19,520 \\
\hline SynSmall & $-9,571$ & 2,338 & 12,241 & $-12,586$ & $-4,112$ & $-4,112$ & $-17,178$ & 13,191 & 13,191 \\
\hline SynLarge & $-13,344$ & $-1,436$ & 8,468 & $-16,359$ & $-7,886$ & $-7,886$ & $-20,951$ & 9,417 & 9,417 \\
\hline
\end{tabular}

$\mathrm{MD}=$ Maryland; $\mathrm{PA}=$ Pennsylvania; $\mathrm{VA}=$ Virginia.

The remaining nurseries (MD-1, MD-3, PA1, PA-2, SynSmall, and SynLarge) have negative net revenue changes for all six plants when $R$ is $0 \%$.

When $R=P_{i}^{\mathrm{w}} / P_{i}^{\mathrm{r}}$, MD-3 and SynLarge have decreased net revenue for Azalea, estimated at $-\$ 1315 /$ ha and $-\$ 1436 /$ ha, respectively. VA-1, MD-3, PA-1, PA-2, SynSmall, and SynLarge have negative changes for Holly, estimated at $-\$ 41 /$ ha, $-\$ 7765 /$ ha, -\$406/ha, -\$2021/ha, -\$4112/ha, and -\$7886/ ha, respectively.

Except for three cases (Holly on MD-3, SynSmall, and SynLarge), all 10 nurseries gain more net revenues for all plants from WRT when the conveyance rate $R=100 \%$ than well water or municipal water. Net revenues increase because the returned premiums generate larger gross revenues to offset the opportunity costs of yield losses as well as the increased production costs with WRT.

Break-even conveyance rate $\mathrm{R}$. For those nurseries that suffer from decreased net revenues associated with WRT for different plants as shown in Tables 11 and 12, the corresponding break-even conveyance rates to balance gross revenue and production cost changes $\left(\Delta \mathrm{NR}_{i}=0\right)$ are shown in Table 13 . For example, for nursery VA-1, a small break-even conveyance rate $R=3.0 \%$ will balance the $-\$ 6275 /$ ha net revenue change associated with WRT for Geranium; whereas for nursery PA-2, a large break-even $R=98.3 \%$ offsets the $-\$ 8327 /$ ha net revenue change related to WRT for Holly. With only three exceptions (Holly on nursery MD-3, SynSmall, and SynLarge), break-even conveyance rates are less than $100 \%$ as shown in Table 13, indicating that growers could cover WRT costs with a sufficient share of consumer premiums.

Break-even premium results. Table 14 shows the break-even premiums corresponding to the break-even $R$ shown in Table 13 that should be returned to growers to balance net revenue. Overall, with only two exceptions (Holly in nursery MD-3 and SynLarge), the break-even premiums are $\$ 0.50 /$ pot or 
less for all plants and all nurseries. Specifically, the break-even premiums for the three annual bedding plants are well below $\$ 0.20$ / pot on average, and are more consistent with previous finding such as Yue et al. (2016), whereas the break-even premiums for the three broad leaf evergreen are slightly higher than previous findings.

Break-even death rate results. The death rate after adoption of WRT is assumed to be nondecreasing based on survey responses reported in Cultice (2013). However, pathogen mitigation practices (Hong and Moorman, 2005) might reduce plant disease incidence below the level obtained without WRT. Reducing plant disease incidence might provide another way to offset additional costs associated with WRT even without returned premiums. Table 15 shows the break-even death rates required to offset the added WRT production costs of nurseries MD-3, PA-1, PA-2, SynSmall, and SynLarge if no premiums are assumed to be returned to producers $(R=0 \%)$. These five nurseries are highlighted because they show an increase in production cost with recycling (Tables 4-7). The results illustrate that for most cases, reducing death rates below $2 \%$, the assumed average rate for non-recycling nurseries, can offset the additional cost incurred from conversion to WRT even without returned premiums. However, there are six exceptions (e.g., Petunia for MD-3) where the death rate would need to be reduced by more than $2 \%$ to offset increased production cost with recycling. A greater than $2 \%$ reduction leads to a physically impossible negative death rate. For these exceptions, reducing plant disease incidence fails to completely offset the added WRT production costs.

\section{Discussion}

Public desire to improve water quality poses environmental challenges for the horticulture industry as demonstrated by policies that require conservation measures. The nursery industry continues to face challenges of reduced product sales resulting from the downturn in the housing market in 2009, although it has partly recovered in recent years. At the same time, the industry faces increasing competition for scarce water supplies in some regions. This study concludes that consumer premiums for plants grown with recycled water could offer nursery growers a method to improve their net returns while addressing environmental challenges and improving irrigation crop water productivity.

Adoption of WRT offers some nurseries the opportunity to reduce water supply costs relative to well water or municipal water. In addition, consumer premiums that could be obtained from plants grown with WRT could outweigh increased production costs of WRT as well as possible economic losses

Table 13. Break-even conveyance rate $R$ required to balance gross revenue and production cost changes $(\Delta N R=0)$.

\begin{tabular}{|c|c|c|c|c|c|c|}
\hline \multirow[b]{2}{*}{ Nursery } & \multicolumn{6}{|c|}{ Break-even $R$} \\
\hline & Geranium (\%) & Petunia $(\%)$ & Chrysanthemum (\%) & Azalea (\%) & Holly (\%) & Boxwood (\%) \\
\hline$\overline{\mathrm{VA}-1}$ & 3.0 & $\mathrm{~N} / \mathrm{A}$ & 3.4 & 16.3 & 28.9 & 38.9 \\
\hline VA-2 & N/A & N/A & $\mathrm{N} / \mathrm{A}$ & $\mathrm{N} / \mathrm{A}$ & $\mathrm{N} / \mathrm{A}$ & N/A \\
\hline VA-3 & 0.5 & N/A & $\mathrm{N} / \mathrm{A}$ & $\mathrm{N} / \mathrm{A}$ & N/A & 21.6 \\
\hline MD-1 & 3.7 & 1.5 & 9.0 & 23.6 & 96.2 & 42.0 \\
\hline MD-2 & 2.6 & N/A & N/A & 13.3 & 69.7 & 34.6 \\
\hline MD-3 & 7.6 & 37.7 & 43.9 & 60.6 & 191.6 & 68.6 \\
\hline PA-1 & 3.7 & 6.3 & 10.9 & 47.7 & 79.2 & 30.4 \\
\hline PA-2 & 4.5 & 13.5 & 17.9 & 55.1 & 98.3 & 35.7 \\
\hline SynSmall & 5.8 & 21.4 & 28.2 & 43.9 & 148.5 & 56.6 \\
\hline SynLarge & 7.6 & 38.2 & 44.5 & 61.2 & 193.1 & 69.0 \\
\hline
\end{tabular}

Note: N/A refers to the case where break-even analysis is not applicable because the net revenue change is already positive without any premium returned as show in Tables 11 and 12 .

Break-even rates greater than $100 \%$ indicate that the estimated consumer premium is not adequate to cover production cost changes.

$\mathrm{MD}=$ Maryland; PA = Pennsylvania; VA = Virginia.

Table 14. Break-even premiums corresponding to the break-even $R$ required to balance gross revenue and production cost changes $(\Delta \mathrm{NR}=0)$.

\begin{tabular}{|c|c|c|c|c|c|c|}
\hline \multirow[b]{2}{*}{ Nursery } & \multicolumn{6}{|c|}{ Break-even premium (\$/pot) } \\
\hline & Geranium & Petunia & Chrysanthemum & Azalea & Holly & Boxwood \\
\hline$\overline{\mathrm{VA}-1}$ & 0.02 & $\mathrm{~N} / \mathrm{A}$ & 0.02 & 0.07 & 0.10 & 0.23 \\
\hline VA-2 & N/A & N/A & N/A & N/A & N/A & $\mathrm{N} / \mathrm{A}$ \\
\hline VA-3 & 0.003 & N/A & N/A & N/A & N/A & 0.13 \\
\hline MD-1 & 0.02 & 0.01 & 0.04 & 0.10 & 0.32 & 0.25 \\
\hline MD-2 & 0.01 & N/A & N/A & 0.06 & 0.23 & 0.21 \\
\hline MD-3 & 0.04 & 0.13 & 0.20 & 0.26 & 0.65 & 0.41 \\
\hline PA-1 & 0.02 & 0.02 & 0.05 & 0.21 & 0.27 & 0.18 \\
\hline PA-2 & 0.02 & 0.05 & 0.08 & 0.24 & 0.33 & 0.22 \\
\hline Syn-S & 0.03 & 0.07 & 0.13 & 0.19 & 0.50 & 0.34 \\
\hline Syn-L & 0.04 & 0.13 & 0.20 & 0.27 & 0.65 & 0.42 \\
\hline
\end{tabular}

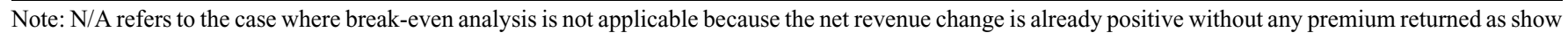
in Tables 11 and 12 .

MD = Maryland; PA = Pennsylvania; Syn-S = SynSmall; Syn-L = SynLarge; VA = Virginia.

Table 15. Break-even death rate to offset added water recycling technology production costs of nurseries MD-3, PA-1, PA-2, SynSmall, and SynLarge when conveyance rate $R=0 \%$.

\begin{tabular}{|c|c|c|c|c|c|c|}
\hline \multirow[b]{2}{*}{ Nursery } & \multicolumn{6}{|c|}{ Break-even death rate } \\
\hline & Geranium (\%) & Petunia $(\%)$ & Chrysanthemum (\%) & Azalea (\%) & Holly (\%) & Boxwood (\%) \\
\hline MD-3 & 1.2 & $\mathrm{~N} / \mathrm{A}$ & $\mathrm{N} / \mathrm{A}$ & 0.7 & 1.1 & 1.4 \\
\hline PA-1 & 2.0 & 1.3 & 1.7 & 1.9 & 1.9 & 1.9 \\
\hline PA-2 & 1.8 & N/A & 0.9 & 1.8 & 1.6 & 1.7 \\
\hline SynSmall & 1.6 & N/A & 0.5 & 1.3 & 1.6 & 1.7 \\
\hline SynLarge & 1.1 & N/A & N/A & 0.7 & 1.1 & 1.4 \\
\hline
\end{tabular}

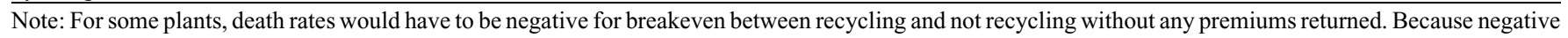
death rates are impossible, such cases are labeled N/A.

$\mathrm{MD}=$ Maryland; PA = Pennsylvania; $\mathrm{VA}=$ Virginia. 
associated with increased plant disease risk. Additional production costs of WRT could also be lowered by reducing plant death rate below levels that occur without WRT (Table 15). Therefore, treatment of recycled water with effective pathogen mitigation procedures should always be considered as suggested by Hong and Moorman (2005).

Nursery growers have diverse production operations and management practices, which depend on location, state and federal policies, market channel, and other considerations. For some nurseries, physical layout restricts the adoption of WRT. For example, limited land or shallow water tables will deter some nurseries from regrading or digging ponds for recycled water, making it impossible to implement WRT regardless of public or private incentives.

Although consumer premiums have potential to make WRT economically feasible for many growers, the logistical resources needed to establish a labeling program for WRT may be beyond the capability of a single horticultural firm. A centralized government or industry organization may be best suited to lead the implementation of certification and labeling of plants grown with WRT. In this case, the "green washing" for WRT practices imposed by sellers, i.e., the act of misleading consumers via promising more environmental benefits of the product than they actually deliver can be effectively mitigated through well-established industry standards and certification programs.

The results of this analysis are specific to only eight case nurseries and two simulated nurseries in mid-Atlantic states. These results should be replicated with a larger set of nurseries and in alternate climate zones. Further analysis could also focus on the upfront costs facing growers who wish to transition to WRT and the length of time required to pay back these costs with alternative recycling premiums. Investments in water-saving technology (e.g., precision watering) provide an alternate way of reducing water use and should be evaluated as well. Researchers should consider the potential for scale economies when evaluating such investments. The premiums estimated by Hartter (2012) were based on hypothetical questions instead of actual marketing experiments. Better estimation of consumer premiums should be possible through experiments involving actual consumer purchases (Chang et al., 2009; Hudson et al., 2012). Additional research should focus on how consumer premiums would be allocated at each distribution stage under different market channels, locations, and plant types. Such research could shed additional light on how consumer premiums for horticultural plants produced with WRT can assist the industry to address environmental challenges.

\section{Literature Cited}

Aguilar, F.X. and R.P. Vlosky. 2007. Consumer willingness to pay price premiums for environmentally certified wood products in the US. For. Policy Econ. 9(8):1100-1112.
Bailey, D., T. Silverback, and D. Bir. 1999. Water considerations for container production of plants. Hort. Info. Lftt. North Carolina State Univ., NC Coop. Ext. Serv. 557.

Behe, B.K., B.L. Campbell, C.R. Hall, H. Khachatryan, J. Dennis, and C. Yue. 2013. Consumer preferences for local and sustainable plant production characteristics. HortScience 48:200-208.

Behe, B.K., B.L. Campbell, H. Khachatryan, C.R. Hall, J.H. Dennis, P.T. Huddleston, and R.T. Fernandez. 2014. Incorporating eye tracking technology and conjoint analysis to better understand the green industry consumer. HortScience 49:1550-1557.

Blumenschein, K., G.C. Blomquist, M. Johannesson, N. Horn, and P. Freeman. 2008. Eliciting willingness to pay without bias: Evidence from a field experiment. Econ. J. (Lond.) 118(525): 114-137.

Chang, J.B., J.L. Lusk, and F.B. Norwood. 2009. How closely do hypothetical surveys and laboratory experiments predict field behavior? Amer. J. Agr. Econ. 91(2):518-534.

Cultice, A.K. 2013. Horticultural producers' willingness to adopt water recycling technology in the mid-Atlantic region. Virginia Polytechnic Inst. State Univ., Blacksburg, Master's Diss.

Cultice, A.K., D.J. Bosch, J. Pease, K.J. Boyle, and W. Xu. 2016. Horticultural growers' willingness to adopt recycling of irrigation water. J. Agr. Appl. Econ. 48(1):99-118.

Cummings, R.G., G.W. Harrison, and E.E. Rutstrom. 1995. Homegrown values and hypothetical surveys: Is the dichotomous choice approach incentive-compatible? Amer. Econ. Rev. 85(1):260-266.

Cummings, R. and L. Taylor. 1999. Unbiased value estimates for environmental goods: A cheap talk design for the contingent valuation method. Amer. Econ. Rev. 89(3):649-665.

Curtis, K.R. and M.W. Cowee. 2010. Are homeowners willing to pay for "origin-certified" plants in water-conserving residential landscaping? J. Agr. Res. Econ. 35(1):118-132.

Dennis, J.H., R.G. Lopez, B.K. Behe, C.R. Hall, C. Yue, and B.L. Campbell. 2010. Sustainable production practices adopted by greenhouse and nursery plant growers. HortScience 45: 1232-1237.

DeVincentis, A.J., R.G. Brumfield, P. Gottlieb, and J. Johnson. 2015. Cost analysis of recycling water in greenhouses in southern New Jersey. HortScience 50:1-6.

Durif, F., C. Boivin, and C. Julien. 2010. In search of a green product definition. Innovative Mktg. 6(1):25-33.

Ferraro, N.K., D.J. Bosch, J.W. Pease, and J.S. Owen. 2017. Costs of capturing and recycling irrigation water in container nurseries. HortScience 52:258-263.

Gardner, J.G., D.B. Eastwood, J.R. Brooker, J.B. Riley, and W.E. Klingeman. 2002. Consumers' willingness-to-pay for powdery mildew resistant flowering Dogwoods. Univ. Tenn. Res. Ser. Accessed 11 July 2015. <https://pdfs. semanticscholar.org/e7b9/b0f69739ad0cb531 fda2a560122e691007c6.pdf $>$.

Halcomb, M. and D. Fare. 2009. Conventional container production. Univ. Tenn. Ext. Accessed 25 June 2015. <http://www.tnstate. edu/faculty/ablalock/documents/Container_ Production_Handout_rev_\%208-10.pdf>.

Harrison, G.W. 2006. Experimental evidence on alternative environmental valuation methods. Environ. Resour. Econ. 34(1):125-162.

Harrison, G.W. and E.E. Rutström. 2008. Experimental evidence on the existence of hypothetical bias in value elicitation methods. Hdbk. Expt. Econ. Results 1:752-767.

Hartter, D.L. 2012. Understanding consumers' ornamental plant preferences for disease-free and water conservation labels. Virginia Polytechnic Inst. and State Univ., Blacksburg, Master Diss.

Hinson, R.A., K.P. Paudel, and M. Velástegui. 2012. Understanding ornamental plant market shares to re-wholesaler, retailer, and landscaper channels. J. Agr. Appl. Econ. 44(2): 173-189.

Hong, C.X. and G.W. Moorman. 2005. Plant pathogens in irrigation water: Challenges and opportunities. Crit. Rev. Plant Sci. 24(3):189208.

Hudson, D., R.K. Gallardo, and T.R. Hanson. 2012. A comparison of choice experiments and actual grocery store behavior: An empirical application to seafood products. J. Agr. Appl. Econ. 44(1):49-62.

Khachatryan, H., B. Campbell, C. Hall, B. Behe, C. Yue, and J. Dennis. 2014. The effects of individual environmental concerns on willingness to pay for sustainable plant attributes. HortScience 49:69-75.

Laroche, M., J. Bergeron, and G. Barbaro-Forleo. 2001. Targeting consumers who are willing to pay more for environmentally friendly products. J. Consumer Mktg. 18(6):503520.

List, J.A. and C.A. Gallet. 2001. What experimental protocol influence disparities between actual and hypothetical stated values? Environ. Resource Econ. 20(3):241-254.

MacDonald, J.M. 2015. Trends in agricultural contracts. Choices 30(3):20 May 2016. https:// ageconsearch.umn.edu/bitstream/207886/2/ cmsarticle_451.pdf.

Maryland Department of the Environment. 2015. Water management permits. Water Management Administration. 22 Mar. 2015. $<$ http://www.mde.state.md. us/programs/Permits/WaterManagementPermits/ Pages/Permits/WaterManagementPermits/>.

Michaud, C., D. Llerena, and I. Joly. 2012. Willingness to pay for environmental attributes of non-food agricultural products: A real choice experiment. Eur. Rev. Agr. Econ. 40(2):313329.

Robbins, J.A. 2010. Irrigation water for greenhouses and nurseries. Arkansas Coop. Ext. Serv. FSA6061. 22 June 2015. <http://www. uaex.edu/Other_Areas/publications/PDF/FSA6061.pdf>.

Schlegelmilch, B.B., G.M. Bohlen, and A. Diamantopoulos. 1996. The link between green purchasing decisions and measures of environmental consciousness. European J. Mktg 30(5):35-55.

Silva, A., R.M. Nayga, Jr., B.L. Campbell, and J. Park. 2007. On the use of valuation mechanisms to measure consumers' willingness to pay for novel products: A comparison of hypothetical and non-hypothetical values. Intl. Food Agribus. Mgt. Rev. 10(2):165-180.

U.S. Bureau of Labor Statistics. 2015. Consumer price index. U.S. Bur. Stat., Washington, D.C. 20 June 2015. <http://www.bls.gov/cpi/>.

U.S. Department of Agriculture, National Agricultural Statistics Service (USDA/NASS). 2014. Census of horticultural specialties, 2012 census of agriculture, volume 3 special studies part 3 AC-12-SS-3. U.S. Dept. Agr., Washington, D.C. 15 June 2015. <https://www.agcensus. usda.gov/Publications/2012/Online_Resources/ Census_of_Horticulture_Specialties/>.

U.S. Environmental Protection Agency (USEPA). 2010. Implementing clean water act section 303(d). 
U.S. Environ. Protection Agency, Washington, D.C. 15 June 2015. <https://www.epa.gov/tmdl>. von Broembsen, S.L. 1998. Capturing and recycling irrigation water to protect water supplies. Water Quality Hdbk. Nurseries. Oklahoma Coop. Ext. Serv. Circular E-951, pp. 27-29. 15 July 2015. $<$ http://www.agwaterquality.org/mgmttools/BMP\% 20document $\% 20$ for $\% 20$ nurserys.pdf $\$$.

White, R.R., M. Brady, J.L. Capper, and K.A. Johnson. 2014. Optimizing diet and pasture management to improve sustainability of US beef production. Agr. Syst. 130:1-12.

Wilson, S.K. and S. von Broembsen. n.d. Water quality series: Capturing and recycling irrigation runoff as a pollution prevention measure. Oklahoma Coop. Ext. Serv. BAE-1518. 15 Aug. 2015. $<$ http://osufacts.okstate.edu/docushare/dsweb/ Get/Document-7408/BAE-1518web.pdf $>$.

Yue, C., B. Campbell, C. Hall, B. Behe, J. Dennis, and H. Khachatryan. 2016. Consumer preference for sustainable attributes in plants: Evidence from experimental auctions. Agribusiness 32(2):222-235.

Yue, C., C.R. Hall, B.K. Behe, B.L. Campbell, J.H. Dennis, and R.G. Lopez. 2010. Are consumers willing to pay more for biodegradable containers than for plastic ones? Evidence from hypothetical conjoint analysis and non-hypothetical experimental auctions. J. Agr. Appl. Econ. 42(4):757-772. 